\title{
NORMAL DEVELOPMENT OF SECONDARY SEXUAL CHARACTERS IN THE SEA URCHIN, ECHINOMETRA MATHAEI
}

\author{
AUTHOR(S): \\ Tahara, Yutaka; Okada, Minoru
}

\section{CITATION:}

Tahara, Yutaka ... [et al]. NORMAL DEVELOPMENT OF SECONDARY SEXUAL CHARACTERS IN THE SEA URCHIN, ECHINOMETRA MATHAEI. PUBLICATIONS OF THE SETO MARINE BIOLOGICAL LABORATORY 1968, 16(1): 41-50

ISSUE DATE:

1968-06-29

URL:

http://hdl.handle.net/2433/175491

RIGHT: 


\title{
NORMAL DEVELOPMENT OF SECONDARY SEXUAL CHARACTERS IN THE SEA URCHIN, ECHINOMETRA MATHAEI ${ }^{12)}$
}

\author{
YUTAKA TAHARA \\ Department of Biology, Osaka Kyoiku University, Osaka \\ and \\ MINORU OKADA \\ Department of Biology, Science Education Institute of Osaka Prefecture, Osaka \\ With Plates I-III, 1 Text-figure and 2 Tables
}

\section{Introduction}

The existence of the conspicuous secondary sexual dimorphism has been found in the shape of the genital papilla in many species of echinoids since HAMAnN (1887) first reported the finding in Echinocardium mediterraneum (Reviewed by TAHARA et al., 1958; Delavault, 1966). This has been confirmed by the present authors in Japanese species of echinoids (TAhara et al., 1958, 1960). Furthermore, they have found among various species of echinoids the following two types of sexual difference of the genital papilla: a) Mespilia type, i.e., the genital papilla of the male is a short, conical protuberance, while that of the female is flat and sunk below the body surface; and b) Tripneustes type, i.e., the male genital papilla forms a slender, long tube, whereas the female forms a short and conical protuberance. The phenomenon has enabled us to identify sexes of live sea urchins. On the other hand this also raises such questions as when and how the secondary sexual dimorphism of the sea urchin becomes established, and what is the factor which determines the secondary sexual differences.

The present paper deals with the first one of these problems. The process of the formation of the genital papilla and of the establishment of its sexual dimorphism has been studied with post-metamorphosed, young adults of a species of sea urchins, Echinometra mathaei as the material. This species was chosen because of its manifestation of the distinct secondary sexual difference in fully grown adults (belonging to Tripneustes type (TAHARA et al., 1958)) and also of easiness to obtain specimens at

1) Supported in part by a grant-in-aid from the Ministry of Education of Japan.

2) Contributions from the Seto Marine Biological Laboratory, No. 485.

Publ. Seto Mar. Biol. Lab., XVI (1), 41-50, 1968. (Article 5) 
various stages of growth. The process of normal development of the gonad has also been observed. The present investigation has disclosed that the formation of the sexual difference in shape of the genital papilla is preceded by the maturation of the gonads.

\section{Material and Methods}

All materials were collected in shallow water near the Seto Marine Biological Laboratory from February through September. July through early September is the breeding season of the present species.

The genital plates of freshly collected specimens were observed under binocular microscope. After measuring the diameter of the test, specimens were dissected, then the genital plates with gonads were excised and fixed in Bouls's mixture for histological preparations. Sections were stained mostly with Delafield's haematoxylin and eosin. MaLlory's triple stain was also employed.

More than 500 specimens have been examined for the determination of the serial stages of development of the genital organs. These stages were determined by gross as well as microscopic morphology of the genital papilla, genital pore and the gonad. The test diameter excluding spines was employed as an additional criterion for staging specimens. Since in Echinometra mathaei the shape of the body is oval from the very beginning of the growing period, both short and long diameters of the test were measured and recorded in such a way as short diameter $\times$ long diameter.

\section{Results}

A group of the smallest specimens of Echinometra mathaei so far obtained in the course of the present study were in quite indifferent conditions regarding their sexuality. Neither the formation of the genital pore nor the differentiation of the gonad into ovary and testis can be detected in them. The development of genital organs and the formation of secondary sexual differences proceed gradually through a definite course which can be divided into the following successive four stages.

Stage 1. Pre-perforation stage

Stage 2. Genital pore formation stage

Stage 3. Genital papilla formation stage

Stage 4. Tripneustes-type papilla stage

Stage 1. Pre-perforation stage

The earliest stage of the development of genital organs so far observed was that of the specimens with test diameter ranging approximately from $4 \times 5$ to $7 \times 9$ $\mathrm{mm}$. This is thus designated from the fact that the perforation of the genital pore has not yet occurred at all.

An external appearance of the aboral region is shown in Plate I, fig. A. Adjoining several plates in the periproct are five genital plates in which the genital aper- 
tures (the genital pores) have not yet been formed. An inside view of the anal region of a dissected animal is given in Text-fig. 1, A and B. The rudimentary gonad can be seen at the aboral end of a ridge-like fold which stretches straight as a transparent thread along the underside of each interradial area (genital ridge). The gonad is hardly perceptible in a fresh specimen at this stage because it is transparent and very minute (about $1 \mathrm{~mm}$ in length).

Longitudinal sections through the genital plate of one of the youngest individuals are shown in Plate I, fig. C. The gonad is a blind tube with a slit-like lumen. No clear distinction can be detected between the genital duct and the gonad. The wall of the gonad consists of an outer visceral peritoneum, a middle connective tissuemuscle layer and an inner germinal epithelium. At this stage the germinal epithelium contains only two types of cells: the immature gonia which can be distinguished from the rest of the cell types by the presence of the clear, round and large nucleus (5-7 $\mu$ ); and the undifferentiated nutritive phagocytes (Holland and Giese, 1965) which show the nucleus of small size $(3-4 \mu)$ with dark stain. These types of cells are packed together in a rather random fashion.

The sex of individuals at this stage can not be identified.

\section{Stage 2. Genital pore formation stage}

Formation of the genital pore takes place in the animals grown to the size approximately $8 \times 10$ to $12 \times 14 \mathrm{~mm}$.

- Genital pore. External appearances of the genital plate are similar in most specimens to those at the previous stage. The genital pore can not be seen from outside. In a few individuals, however, the first sign of the genital pore appears as a slight depression near the distal margin of the genital plate (Plate I, fig. B). The center of the shallow hole thus formed is usually paler in color than the surrounding area.

Histological sections through the genital plates of many individuals reveal a series of developmental changes of the genital pore. An evagination of the epithelial cells and the connective tissue fibers into the ossicle of the genital plate begins to take place in the area where the gonad is connected to the genital plate by the peritoneal membrane (Plate I, fig. D). This figure also suggests an active movement of cells occurring at the base of the evaginating gonoduct. A perforation of the genital pore proceeds further as the epithelial cells of the genital duct actively go into the reticulum of the genital plate (Plate I, fig. E). The connective tissue fibers surrounding the duct appear to accompany the evagination movement of the epithelial cells. The lumen of the genital duct is lacking or slit-like at first, but gradually becomes wider as the perforation proceeds. Towards the end of this stage the genital duct reaches just beneath the skin epidermis as shown in Plate I, fig. F. The wall of the duct thus formed is lined by a layer of the epithelial cells which are surrounded by thin layers of connective tissue fibers. A perforation of the duct to the exterior through the skin has not been accomplished at this stage. 


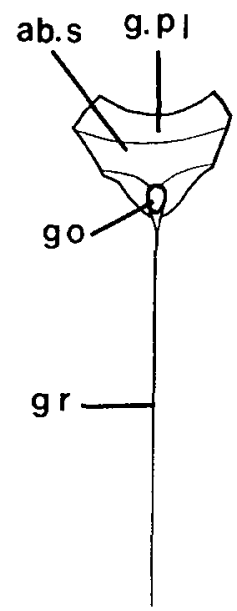

A

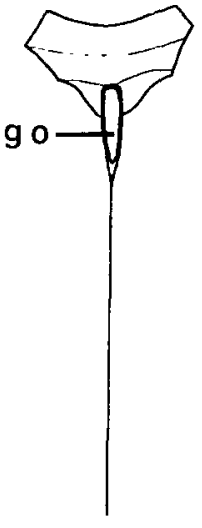

B

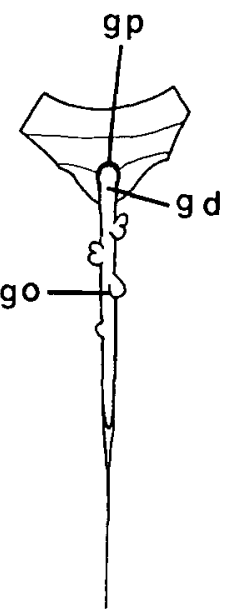

C

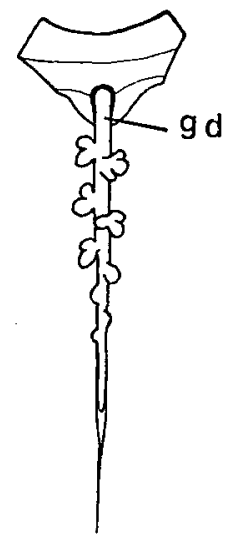

D

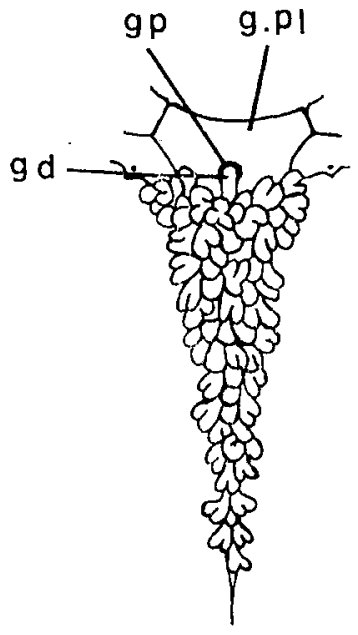

$E$

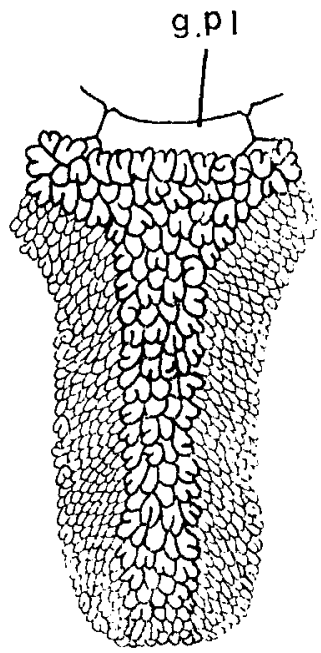

F

Test-fig. 1. External appearances of developing gonad seen from oral side. A and B, Stage 1; C and D, Stage 2; E, Stage 3; F, Stage 4. ab.s, aboral sinus; gd, genital duct; go, gonad; gp, genital pore; g. pl, genital plate; gr, genital ridge. 
Gonad. The gonad shows a remarkable elongation towards oral side along the genital ridge. In most specimens more than three (3 to 15) bud-like branches can be seen on either side of the tubular gonad (Text-fig. 1, C, D). This is the earliest stage of acinus formation in gonad.

On sections the gonad shows a tubular structure with a definite lumen in the specimens in the early phase of this stage (Plate I, fig. G). The germinal epithelium consists of two types of cells, the gonial cells and the nutritive phagocytes. The arrangement of these cells becomes regular, i.e., the gonial cells occupy the outer part of the wall attached to the layer of the connective tissue fiber, whereas the nutritive phagocytes cover the gonial cells facing the lumen of the gonad. The latter also start to change their shape into the mesenchymal cells which do not contain cytoplasmic globules. Plate 1 , fig. $H$ shows a section through an acinus of the gonad of a specimen in the later phase of Stage 2. The wall of the gonad becomes stretched very thin as the gonad grows remarkably during this stage. The lumen of the gonad becomes much wider and at the same time filled with the network of non-globulated nutritive phagocytes. A relatively small number of the gonial cells scatter throughout the gonad attached to the connective tissue-muscle layer. The genital duct can be distinguished from the gonad histologically at this stage.

There can not be detected any differentiated sex cells beyond the gonial stage. Therefore, it may be considered that this is a still sexually undifferentiated stage.

In specimens of this stage there can frequently be found a characteristic structure, an islet, consisting only of some fifty or less of the primordial germ cells. It lies at one end of the genital duct protruding towards the anal direction (Plate II, figs. A, B). Some cells can also be found in the lumen of the genital duct isolated from the islet as shown in Plate II, fig. A. Although the functions of this structure are not ascertained as yet, it can be assumed that the islet may be an accumulation of the primordial germ cells and consequently may serve as a supplying sourse of the gonial cells to the gonad.

\section{Stage 3. Genital papilla formation stage}

The genital papilla appears first in the specimens with the test diameter roughly ranging from $13 \times 15$ to $19 \times 22 \mathrm{~mm}$, in which it becomes possible to identify sexes by examining genital products in their gonads.

Genital papilla. Three types in the shape of the genital papilla are distinguishable at this stage: slender and tubular, conical or wart-like, and flat. An actual photograph of the conical papillae is shown in Plate II, fig. C.

The distribution of these types of genital papillae among the male and female identified by gonad was examined and the results are summarized in Table 1. The Table demonstrates that a) the conical or wart-like papillae are the predominant type in the Stage 3 individuals and they occur in almost the same percentage, about $65 \%$, both in the male and female, b) more males tend to have comparatively 
Table 1. Distribution of three types of shape of the genital papilla among young males and females (Stage 3).

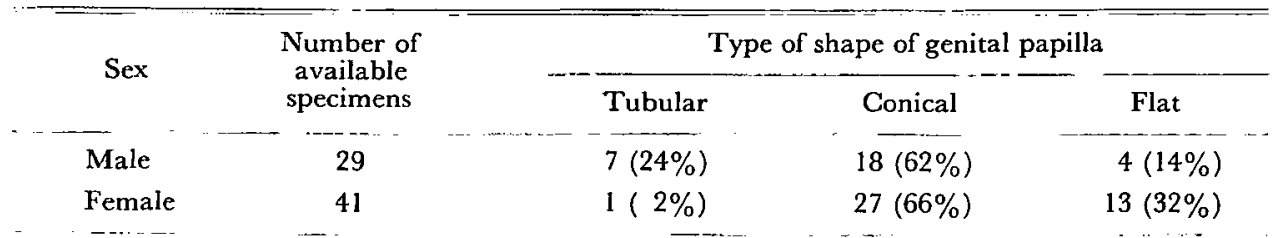

long and slender papillae, and c) more females, on the contrary, flat ones. It can be concluded, from the results, that the establishment of the secondary sexual dimorphism has not yet been completed at this stage, although it is in the process of differentiation.

Plate II, fig. D is a longitudinal section through a conical papilla showing an elevation of the skin epidermis and formation of the basement membrane beneath the epithelial lining of the genital duct. A perforation of the duct to the exterior through the skin has not yet been accomplished in any individual so far examined microscopically.

Gonad. An external appearance of the gonad is shown in Text-fig. 1, E. The branching of the acinus becomes multiplied and complicated. Each acinus has so much grown and thickened that the appearance of the gonad becomes voluminous at this stage. A transverse section of the gonad is triangular in shape. A few individuals in which the gonad is filled with the genital products, show a clear difference in the color of the gonad between the male and female; the ovary is deep yellow tinged with light red, whereas the testis is creamy yellow or whitish.

Various stages of differentiating spermatocytes or growing oöcytes can be found on sections through acinus of the testis or the ovary (Plate II, figs. E, F). Besides sex cells, the deglobulated or globulated nutritive phagocytes can be found in the lumen of the gonad. Ripc sexual products, eggs and sperms, can produce the pluteus larvae by artificial insemination. Therefore, individuals of this stage are sexually matured.

\section{Stage 4. Tripneustes-type papilla stage}

The distinct sexual dimorphism can be detected in the shape of the genital papilla (Tripneustes type) in specimens with test diameters over $20 \times 23 \mathrm{~mm}$. The maximum size so far observed is $40 \times 47 \mathrm{~mm}$.

Genital papilla. The genital papilla shows two types of shape at this stage. A slender, tubular papilla with a pointed end is usually found in the male (Plate III, fig. A), while a stumpy, conical papilla with an obtuse end can be seen in most females (Plate III, fig. B). In typical cases the length of the male papilla is more than half of that of the spinules which are found near the papilla, whereas the height of the female papilla is always less than half of that of the neighbouring spinules. No papilla of the flat type can be found at this stage. 
Table 2. Distribution of two types of shape of genital papilla among fully grown males and females (Stage 4).

\begin{tabular}{lcrr}
\hline Sex & $\begin{array}{c}\text { Number of } \\
\text { available } \\
\text { specimens }\end{array}$ & Type of shape of genital papilla \\
\hline Male & 54 & $47(87 \%)$ & Conical \\
Female & 54 & $6(11 \%)$ & $7(13 \%)$ \\
\hline
\end{tabular}

Table 2 shows a pattern of distribution of the two types of genital papillae among fully matured males and females. It is indicated that besides the individuals showing the shape of the papilla typical of respective sexes, there can be found a few specimens (about $13 \%$ of males and females) which manifest the secondary sexual characteristics of the opposite sex.

Histological sections through the genital papillae (Plate III, figs. C, D) disclose that the genital duct is always found to be opened to the exterior at the tip of the genital papilla. It is quite probable that the perforation of the duct through the skin epidermis occurs at the time of the first spawning. The histological aspects of the genital papilla do not show any other distinct difference between sexes than that in the degree of elevation of the skin epidermis. The differentiation of some specially thickened fibers among the connective tissue fibers can be found both at upper and lower rims of the genital pore. They connect the genital duct to the ossicle of the plate supporting the former.

Gonad. An external appearance of the gonad is quite similar in both sexes (Text-fig. 1, F). The color of the gonad differs only when the gonad is filled with the genital products as in the previous stage.

The histological section through the ovary or testis of a fully matured individual also reveals a definite resemblance in the structure of the gonad wall in both sexes. The gonad wall of the present species can also be divided into the three main layers as described by WiLson (1940) on Arbacia punctulata.

\section{Conclusions and Considerations}

Based upon the results obtained from the present observations, the process of the formation of the sexual difference in the shape of the genital papilla in Echinometra mathaei can be figured out as follows. After the perforation of the genital pore is completed (Stage 2), the genital papilla appears first as a relatively flat, mound-like elevation of the skin over the genital pore (early phase of Stage 3). Then, the papilla is elevated further to form a conical or wart-like protuberance in both sexes (later phase of Stage 3). In males, the conical papilla continues to grow further until it comes to form a slender, tubular protrusion, whereas in females it retains its conical shape thereafter (Stage 4).

Table 1 indicates that at Stage 3 the genital papillae are predominantly conical 
in shape, which occur in nearly the same percentage both in the male and female, more males showing longer papillae than females, and more females forming flat ones than males. The gonads of every specimen, on the other hand, are well differentiated into ovary and testis and contain the ripe genital cells at the same stage. It may, therefore, be concluded that the maturation of the gonad is achieved prior to the establishment of the secondary sexual difference.

TokıoKA's recent report (1966) suggests that Echinometra mathaei, in natural habitat near the Seto Marine Biological Laboratory (Tanabe Bay), grows up to the size of about $20 \mathrm{~mm}$ (long diameter excluding spines ) in early summer of the second year after fertilization and about $35 \mathrm{~mm}$ in the same season of the third year. The animals with such sizes can be referred to as the Stage 3 and the Stage 4 individuals respectively. In other words, a fertilized Echinometra egg takes almost one year to grow up to the genital papilla formation stage (Stage 3 ) and one and a half or two years to attain the Tripneustes-type papilla stage (Stage 4).

\section{Summary}

1. The present study has been carried out to elucidate the problem, when and how the secondary sexual dimorphism of the sea urchin is established, with Echinometra mathaei as the material.

2. The process of normal development of the genital organs (genital pore, genital papilla, and gonad) was observed and divided into four stages: Stage 1, Preperforation stage; Stage 2, Genital pore formation stage; Stage 3, Genital papilla formation stage; Stage 4, Tripneustes-type papilla stage.

3. The process of the formation of the secondary sexual difference in the shape of the genital papilla can be figured out as follows. The papilla appears first as a relatively flat elevation of the skin over the genital pore (early phase of Stage 3). Then, the papilla is elevated further to form a conical or wart-like protuberance in both sexes (later phase of Stage 3). The gonad accomplishes its differentiation into ovary and testis and also its maturation at this stage. In males, the conical papilla continues to grow further until it comes to form a slender, tubular protrusion, whereas in females it retains its conical shape thereafter (Stage 4).

4. The temporal relations of the appearance of the sexual difference in the shape of the genital papilla to the differentiation of the gonad have been discussed.

\section{Acknowledgement}

The authors wish to express their cordial gratitude to Prof. UTinom and Dr. TокіокA of the Seto Marine Biological Laboratory who have read the manuscript. They are deeply indebted to all other staffs of the Laboratory and express their hearty thanks to them for all conveniences offered in the course of the present investigations. 


\section{REFERENCES}

Delavault, R. 1966. Determination of sex. In "Physiology of Echinodermata", (ed. R.A. Boolootian), pp. 615-638. Interscience Publisher, New York.

HamanN, O. 1887. Beiträge zur Histologie der Echinodermen. Jena. Zeits. N.F., Vol, 14(21), pp. 87-266.

Holland, N.D. and Giese, A.C. 1965. An autoradiographic investigation of the gonads of the purple sea urchin (Strongylocentrotus purpuratus). Biol. Bull. mar. biol. Lab., Woods Hole, Vol. 128(2), pp. 241-258.

Tahara, Y., OKada, M. and Kobayashi, N. 1958. Secondary sexual characters in Japanese seaurchins. Publ. Seto Mar. Biol. Lab., Vol. 7(1), pp. 165-172.

Tahara, Y., Okada, M. and Kobayashi, N. 1960. Further notes on the sexual dimorphisms in Japanese sea urchins. Publ. Seto Mar. Biol. Lab., Vol. 8(1), pp. 183-189.

TокіокA, T. 1966. Recovery of the Echinometra population in the intertidal zone in the vicinity of Seto, with a preliminary note on the mass mortality of some sea urchins in the summer season. Publ. Seto Mar. Biol. Lab., Vol. 14(1), pp. 7-16.

Wilson, L.P. 1940. Histology of the gonad wall of Arbacia punclulata. J. Morph., Vol. 66, pp. 463479 .

\section{EXPLANATION OF PLATES}

\section{Plate I}

Fig. A. An aboral view of a very young urchin (Stage 1) showing five genital plates. $\times 15$.

Fig. B. An aboral view of a Stage 2 specimen showing the genital pores just formed (arrows). $\times 12$.

Fig. C. A longitudinal section through the gonad (go) of a Stage 1 specimen. ab. $s$, aboral sinus; vp, visceral peritoneum. $\times 150$.

Fig. D. A longitudinal section through the genital organs of a Stage 2 specimen showing the gonad (go) and the perforating genital pore (gp). $\times 480$.

Fig. E. A section through the genital plate of a Stage 2 specimen showing the perforating genital pore (gp). ab.s, aboral sinus. $\times 150$.

Fig. F. A section through the genital pore (gp) of a Stage 2 specimen. The genital duct reaches just beneath the skin epidermis. $\times 120$.

Fig. G. A longitudinal section through the gonad of a Stage 2 specimen. ct, connective tissue-muscle layer; $\mathrm{g}$, gonial cell; $\mathrm{np}$, nutritive phagocytes; $\mathrm{vp}$, visceral peritoneum. $\times 480$.

Fig. H. A section through an acinus of the gonad of a Stage 2 specimen showing the network of the nutritive phagocytes (np) and gonial cell (g). ct, connective tissue-muscle layer. $\times 480$.

\section{Plate II}

Fig. A. A section through an islet of the primordial germ cells (arrow). One of the PGCs is seen in the genital duct (gd). vp, visceral peritoneum. $\quad \times 840$. 
Fig. B. A section through an islet of the PGCs showing its location. gd., genital duct; vp, visceral peritoneum. $\times 480$.

Fig. C. An aboral view of a Stage 3 specimen showing the conical papillae (arrows). $\times 10$.

Fig. D. A longitudinal section through a conical papilla of a Stage 3 urchin (female). bm, basement membrane. $\times 120$.

Fig. E. A section through the testis of a Stage 3 specimen showing the sex cells and nutritive phagocytes. $\times 360$.

Fig. F. A section through the ovary of a Stage 3 specimen showing the sex cells and nutritive phagocytes. $\times 360$.

\section{Plate III}

Figs. A-D. The genital papillae of fully grown individuals (Stage 4).

Fig. A. A genital papilla of the male. Note the length of the papilla (arrow) comparing with a spinule standing close to it. $\times 13$.

Fig. B. A genital papilla of the female (arrow). $\times 13$.

Fig. C. A longitudinal section through a male genital papilla. Arrows indicate some thickened fibers at the upper rim of the genital pore. bm, basement membrane. $\times 120$.

Fig. D. A longitudinal section through a female genital papilla. An arrow indicates some thickened fibers at the upper rim of the genital pore. bm, basement membrane. $\times 120$. 

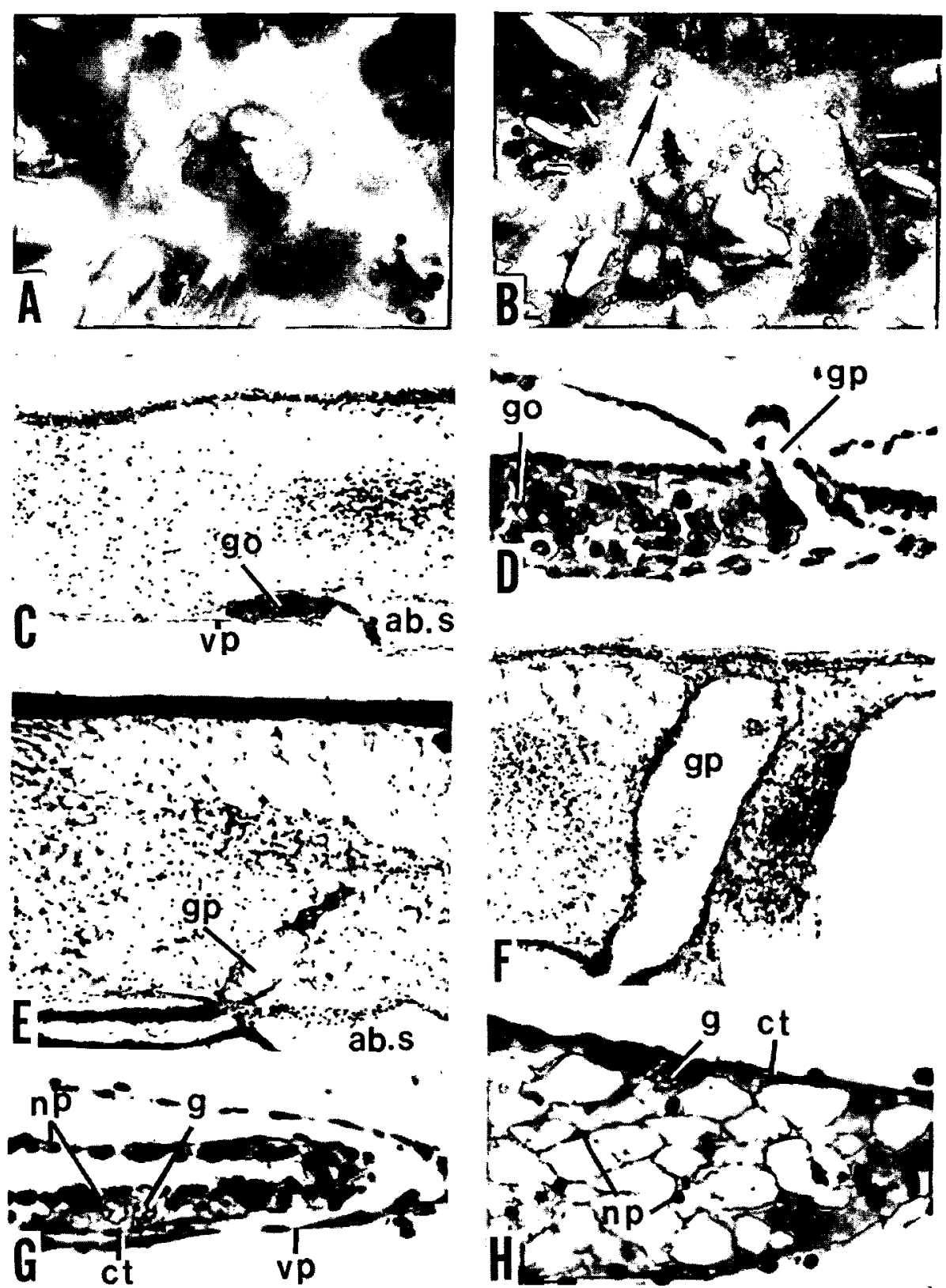

Y. TAHARA and M. OKADA: Development of Secondary Sexual Characters in Echinometra mathaei 
Publ. Seto Mar. Biol. Lab., XVI (1), 1968.
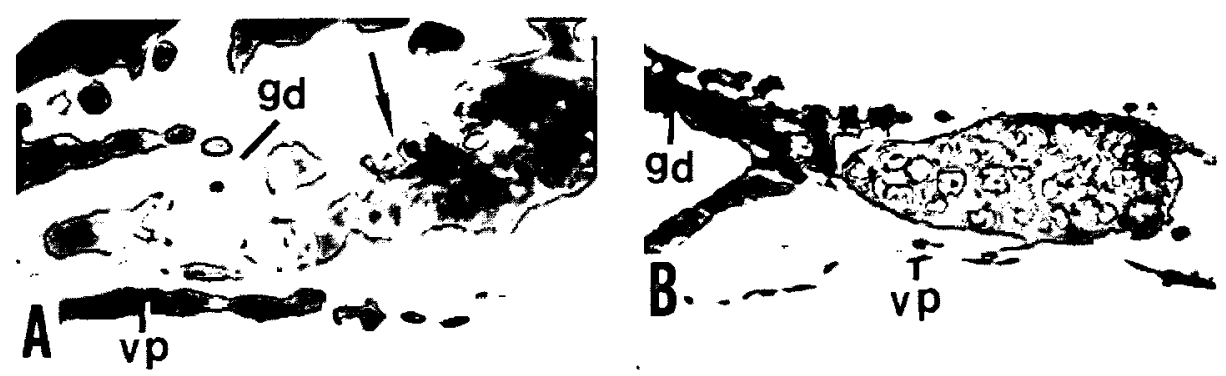

0
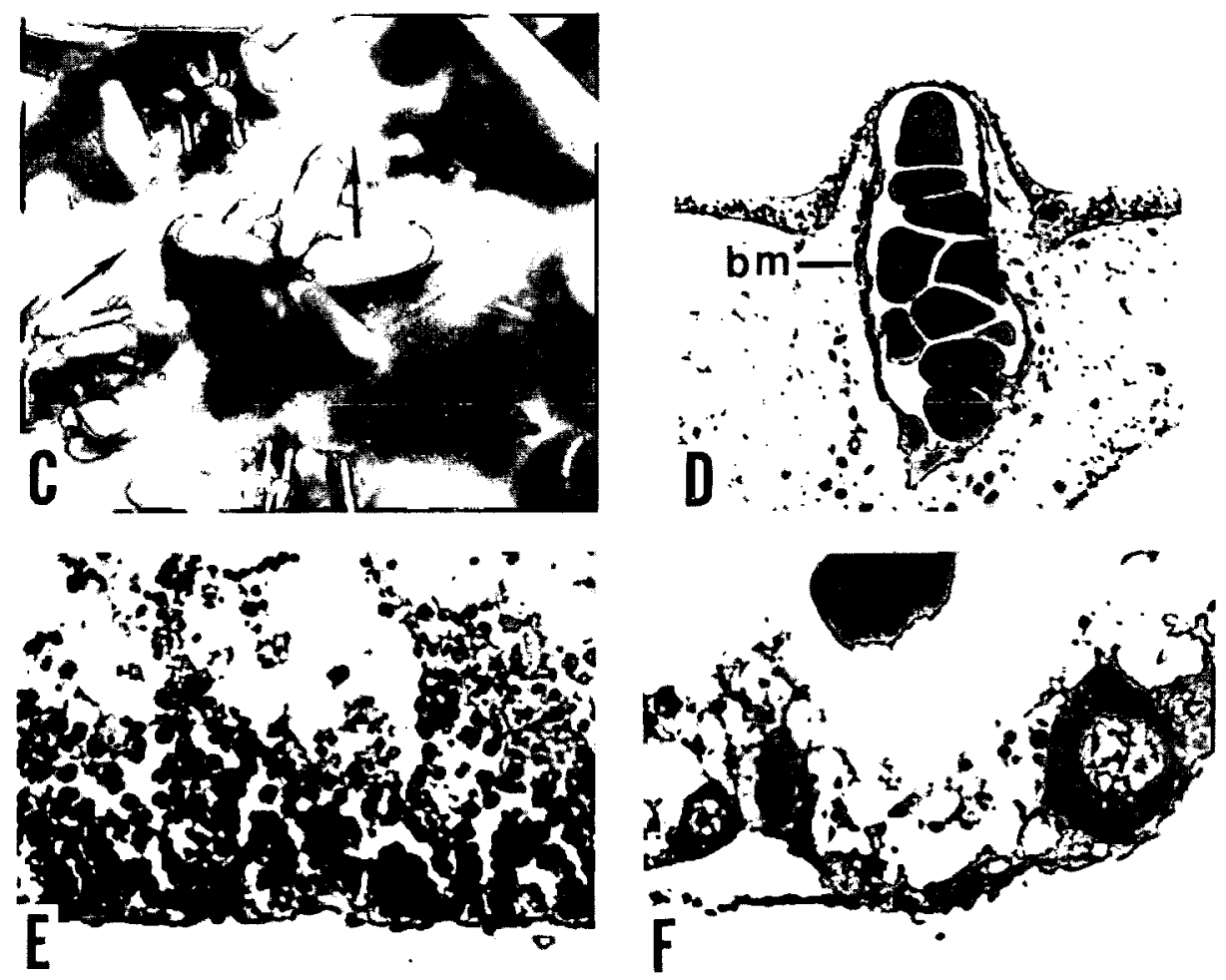

Y. TAhara and M. OKada: Development of Secondary Sexual Characters in Echinometra mathaei 
Publ. Seto Mar. Biol. Lab., XVI (1), 1968
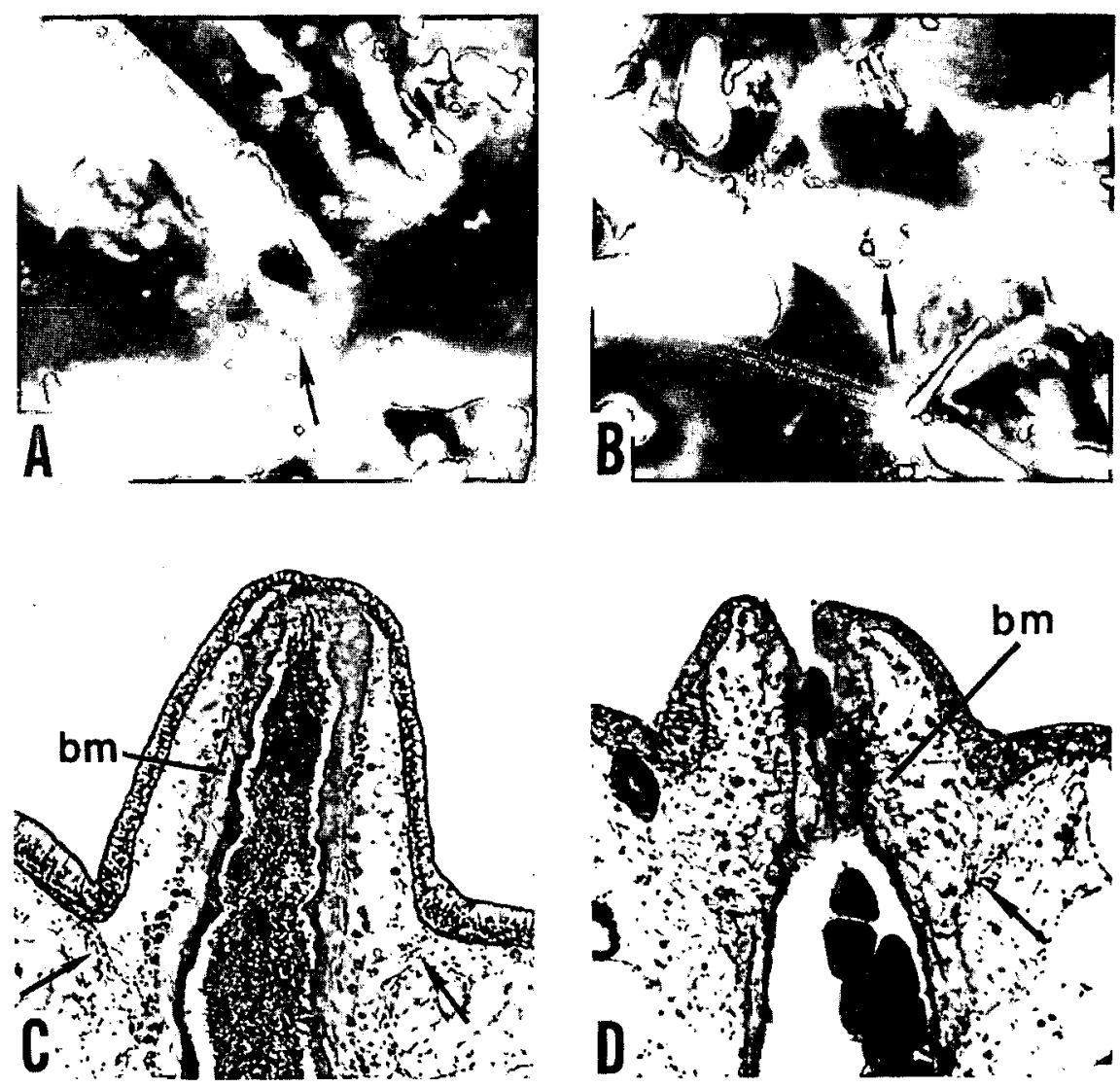

Y. TAHARA and M. OKada: Development of Secondary Sexual Characters in Echinometra mathaei 